Article

\title{
Characterization and Sorptivity of the Plesiomonas shigelloides Strain and Its Potential Use to Remove $\mathrm{Cd}^{2+}$ from Wastewater
}

\author{
Chao Xue ${ }^{1,2}$, Peishi Qi ${ }^{1,2, *}$, Mengsha $\mathrm{Li}^{3}$ and Yunzhi Liu ${ }^{1,2}$ \\ 1 State Key Laboratory of Urban Water Resource and Environment, Harbin Institute of Technology, \\ Harbin 150090, China; xuechao1986@163.com (C.X.); liuyunzhi0907@163.com (Y.L.) \\ 2 School of Municipal and Environmental Engineering, Harbin Institute of Technology, Harbin 150090, China \\ 3 Institute of Nature Resources and Ecology, Heilongjiang Academy of Sciences, Harbin 150040, China; \\ limengsha19861004@163.com \\ * Correspondence: qipeishi@163.com; Tel.: +86-186-868-67821
}

Academic Editor: Miklas Scholz

Received: 20 April 2016; Accepted: 30 May 2016; Published: 3 June 2016

\begin{abstract}
In this study, the ability of adsorbing $\mathrm{Cd}^{2+}$ ions of Plesiomonas shigelloides was discovered. Herein, the method and mechanisms of adsorbing $\mathrm{Cd}^{2+}$ ions from aqueous solutions is discussed. The cadmium-resistant bacterium was collected from the sediment of Harbin section of the Songhua River in China, and then isolated, identified and characterized. The isolated strain was identified as Plesiomonas shigelloides H5 on the basis of morphological and biochemical characteristics, the sequencing of the 16SrDNA gene, and phylogeny analysis. P. shigelloides H5 was Gram-negative and bacillus. Maximum tolerance concentration (MTC) of the strain was $150 \mathrm{mg} / \mathrm{L}$. The maximum adsorption rate and adsorption amounts was $42.71 \% \pm 0.88 \%$ and $106.775 \pm 2.325 \mathrm{mg} / \mathrm{g}$ when dried biomass was presented in a $50 \mathrm{mg} / \mathrm{L} \mathrm{Cd}^{2+}$ solution. Dried biomass was in accordance with Lagergren pseudo-second-order models. A field emission scanning electron microscope (FE-SEM), an energy dispersive X-ray spectrometer (EDX), and Fourier transform infrared spectroscopy (FTIR) analyses were applied to identify the surface morphology and functional groups. Transmission electron microscope (TEM) results showed that $\mathrm{Cd}^{2+}$ was also absorbed into cells to form precipitates. The results revealed that the surface functional groups of $P$. shigelloides $\mathrm{H} 5$ can bind to heavy metal ions. To sum up, the ability of adsorbing cadmium ions of Plesiomonas shigelloides was discovered, which might be helpful in wastewater treatment in the future.
\end{abstract}

Keywords: cadmium removal; Plesiomonas shigelloides; biosorption; bioremediation

\section{Introduction}

Environmental cadmium pollution usually comes from power stations, metallurgy, electroplating, dye, waste incineration processing, cement production, etc. Agricultural production with the content of cadmium in fertilizer applications and atmospheric cadmium dust settlement will cause cadmium accumulation and pollution [1,2]. Cadmium is widely distributed in nature, but is scarcely found in the Earth's crust. Normal soil contains $0.03-0.3 \mathrm{mg} / \mathrm{kg} \mathrm{Cd}^{2+}$, usually no more than $1 \mathrm{mg} / \mathrm{kg}$. An amount of $2.81 \mathrm{mg} / \mathrm{kg}$ of $\mathrm{Cd}^{2+}$ is extremely high in the sediments of coastal wetlands in Southeast China [3]. The Arctic Monitoring Assessment Program reported that observed levels of cadmium in some marine birds and animals are high enough to be of concern [4]. Cadmium selectively accumulates in the pancreas, bones, liver and lungs. It affects cell proliferation, differentiation, and apoptosis and increases the likelihood of developing cancer [5]. It also causes bone-thinning disease, osteoporosis, fractures, toxicity to the neuron, aging and respiratory tract problems [6,7]. 
Conventional methods to remove cadmium by precipitation, flocculation, and membrane filtration are exceedingly expensive and hardly effective at low concentrations [8,9]. However, numerous microorganisms can evolve the ability of anti-heavy metals or adsorb heavy metals in the long-term heavy metal pollution environment [10-12]. Consequently, many researchers used bacteria or algae as new bioremediation technology to remove cadmium [13]. For example, sulfate reducing bacteria could remove cadmium from wastewater by generating biological iron sulfide composites [14]. Exopolysaccharide of pseudomonas can promote adsorption of heavy metals $[15,16]$ and some bacteria can also reduce metalloid oxyanions [17,18].

The aim of this study is to isolate cadmium-resistant microorganisms that can adsorb $\mathrm{Cd}^{2+}$ and then to investigate biosorption mechanisms. The cadmium-resistant strain was isolated and identified as Plesiomonas shigelloides H5, based on morphological observation, biochemical and physiological characterizations, and 16SrDNA sequence analysis. The maximum tolerated concentrations (MTC), the optimal growth conditions of bacteria, and the cadmium sorption rate were determined. A transmission electron microscope (TEM) was used to verify absorptivity of the isolated strain. Furthermore, FE-SEM, EDX, and FTIR analyses were carried out to identify the surface morphology and functional groups. The adsorption mechanisms were investigated with adsorption kinetic models.

\section{Materials and Methods}

\subsection{Sediment Analysis and Cadmium-Resistant Bacteria Isolation}

Six sediment samples were collected from the Songhua River of China, which has been heavily polluted by toxic wastewater from electric appliance factory, chemical materials factory, and other industrial activities. Sampling spots were selected near the HeJia Stream (North $45^{\circ} 75^{\prime} 47^{\prime \prime}$, East $\left.126^{\circ} 57^{\prime} 57^{\prime \prime}\right)$.

For the isolation of cadmium-resistant bacteria, $5 \mathrm{~g}$ of collected sediment samples were $10^{5}$ fold serial dilutions. A portion of $0.15 \mathrm{~mL}$ of final dilution was subjected to the culture dish on beef extract peptone agar medium with $10 \mathrm{mg} / \mathrm{L} \mathrm{Cd}^{2+}$ (BEPA-Cd composition $\mathrm{L}^{-1}: 3.0 \mathrm{~g}$ beef extract, $10.0 \mathrm{~g}$ peptone, $0.5 \mathrm{~g} \mathrm{NaCl}, 15.0 \mathrm{~g}$ agar, $0.0684 \mathrm{~g} 3 \mathrm{CdSO}_{4} \cdot 8 \mathrm{H}_{2} \mathrm{O}, 1000 \mathrm{~mL}$ deionized water) and incubated in a bacteriological incubator at $30^{\circ} \mathrm{C}$ for $24 \mathrm{~h}$. Isolates were selected and re-streaked on BEPA-Cd plates at $30^{\circ} \mathrm{C}$ for $24 \mathrm{~h}$. The process was repeated until the pure culture cadmium-resistant strain was obtained.

\subsection{Identification and Characterization of the Cadmium-Resistant Bacteria}

The shape and colors of the pure culture cadmium-resistant bacteria strain was evaluated under the optical microscope after Gram staining. The biochemical characteristics of the isolated strain were analyzed with the API 20E Gram-negative bacteria assay system (Biomerieux, France). The 16srDNA of the isolated strain was extracted by using the Genomic DNA Purification Kit (Promega, Fitchburg, WI, USA) after enrichment culture. Bacterial genome was amplified with 16SrDNA universal primers: 27F (5-AGAGTTTGATCCTGGCTCAG-3) and 1492R (5-TACGGTTACCTTGTTACGACTT-3) using a polymerase chain reaction (PCR) as described [19]. The PCR was performed with a 50- $\mu \mathrm{L}$ reaction mixture containing $1 \mu \mathrm{L}$ (500 ng) of 16srDNA genome as a template, each primer at a concentration of $1.0 \mu \mathrm{M}$, dNTPs at a concentration of $2.5 \mathrm{mM}, 5 \mu \mathrm{L} 10 \times$ Ex Taq Buffer, and $1.25 \mathrm{U}$ of TaKaRa Ex Taq polymerase (TaKaRa, Dalian, China). The initial denaturation step was performed at $94{ }^{\circ} \mathrm{C}$ for $5 \mathrm{~min}$, followed by 35 cycles of $10 \mathrm{~s}$ of denaturation at $98^{\circ} \mathrm{C}$, then annealed for $30 \mathrm{~s}$ at $55^{\circ} \mathrm{C}$, and elongated for $90 \mathrm{~s}$ at $72{ }^{\circ} \mathrm{C}$. The last step was extension at $72{ }^{\circ} \mathrm{C}$ for $10 \mathrm{~min}$. PCR products were analyzed by $1.2 \%$ $w / v$ agarose gel electrophoresis in $1 \times$ TAE buffer with gel-red. The PCR products were purified by Gel Extraction Kit (Invitrogen, Waltham, MA, USA) and sent to Genewiz Biotech Co. Ltd. (South Plainfield, NJ, USA) for sequencing. 


\subsection{Experiment on Optimal Culture Conditions}

The $\mathrm{pH}$ and temperature of culture were monitored. The isolated strain was cultured in BEP medium with cadmium stress $\left(20 \mathrm{mg} / \mathrm{L}, 3 \mathrm{CdSO}_{4} \cdot 8 \mathrm{H}_{2} \mathrm{O}\right)$ at different $\mathrm{pH}$ values ranging from 1.0 to 13.0 and incubation was carried out at ten different temperatures from 5 to $50^{\circ} \mathrm{C}$, as well as a control group. The bacterial growth rate was measured at $600 \mathrm{~nm}$ (OD600) after culture for $20 \mathrm{~h}$ with $1 \%$ cultural inoculum concentration. Three biological replicates were used in the experimental design.

\subsection{Experiment on Maximum Tolerance Concentrations}

The maximum tolerance concentrations (MTC) were carried out by increasing the concentration of $\mathrm{Cd}^{2+}$ in the medium. The isolated bacterial strain was inoculated into $20 \mathrm{~mL}$ of BEP-Cd medium supplemented with different $\mathrm{Cd}^{2+}$ concentrations $(20,40,100,150$, and $200 \mathrm{mg} / \mathrm{L}$ ). Cultures were incubated in a bacteriological incubator $\left(35^{\circ} \mathrm{C}\right)$ for $30 \mathrm{~h}$. The bacterial growth rate was measured at $600 \mathrm{~nm}$, and the highest cadmium ion concentration at which the bacteria can grow was designated as the MTC. Three biological replicates were used in the experimental design.

\subsection{FTIR, SEM, EDX, and TEM Analysis}

The isolated strain was cultured in medium containing $20 \mathrm{mg} / \mathrm{L}$ cadmium at $35{ }^{\circ} \mathrm{C}$ for $24 \mathrm{~h}$. Ten mL supernatant fluid was collected by centrifugation at $5000 \mathrm{rpm}$ for $15 \mathrm{~min}$ and washed four times with phosphate buffer saline solution ( $\mathrm{pH}$ 7.3). Then, bacterial pellets were freeze-dried for $24 \mathrm{~h}$ and analyzed by FTIR spectrometer (Bruker, Karlsruhe, Germany). FTIR spectra were collected in the 400 to $4000 \mathrm{~cm}^{-1}$ region. Bacterial pellets were fixed by $2.5 \%(v / v)$ glutaraldehyde for $2 \mathrm{~h}$. After that, bacterial pellets were dehydrated in 25\%,50\%,75\%,90\%, and 100\% (v/v) ethanol for $20 \mathrm{~min}$ each. Then, samples were freeze-dried for $24 \mathrm{~h}$ to observe surface morphologies under emission scanning electron microscope (FE-SEM) (JEOL, Tokyo, Japan) at $5.0 \mathrm{kV}$, field equipped with an energy-dispersive X-ray spectrometer (Oxford, UK). In TEM analysis, bacterial pellets were washed three times with deionized water and fixed by $1 \%(w / v)$ osmium tetroxide for $3 \mathrm{~h}$. After fixing, the sample was dehydrated in $50 \%, 75 \%, 90 \%$, and $100 \%(v / v)$ ethanol for $15 \mathrm{~min}$ each. Then, the sample was incubated in the mixture of acetone and epoxy resin $(v / v=2 / 1$ for $3 \mathrm{~h}, v / v=1 / 2$ for $12 \mathrm{~h})$ in epoxy resin for $3 \mathrm{~h}$. The sample was centrifugated, embedded in solid resin blocks for $24 \mathrm{~h}$ at $60^{\circ} \mathrm{C}$, and then sectioned on an ultramicrotome. Sections were analyzed by transmission electron microscopy (Hitachi, Tokyo, Japan).

\subsection{Cadmium Sorption Experiments}

Dried biomass was prepared from washed cells, which were autoclaved at $121{ }^{\circ} \mathrm{C}$ for $20 \mathrm{~min}$ and dried in an oven at $60^{\circ} \mathrm{C}$ for $24 \mathrm{~h}$, and then grounded into powder. For the sorption experiments, $2 \mathrm{~mL}$ of $5 \times 10^{9}$ cells $/ \mathrm{mL}$ living biomass (equal to $10 \mathrm{mg}$ ) and $2 \mathrm{~mL}$ of dried biomass $(10 \mathrm{mg}$ ) were added into Erlenmeyer flasks containing $50 \mathrm{~mL}$ of $50 \mathrm{mg} / \mathrm{L}$ cadmium solutions, respectively. Living Escherichia coli DH5 $\alpha$ was used as a negative control. The effects of different $\mathrm{pH}$-values (2 to 7 ) and temperatures $\left(20\right.$ to $40^{\circ} \mathrm{C}$ ) on the adsorption were also studied. The $\mathrm{pH}$ was adjusted to $2,3,4,5,6$, and 7 with $1 \mathrm{M}$ nitric acid and $1 \mathrm{M}$ sodium hydroxide before adding the adsorbent. Erlenmeyer flasks were placed in a thermostat incubator for $48 \mathrm{~h}$. A portion of $20 \mathrm{~mL}$ supernatant fluid was collected and centrifuged at $5000 \mathrm{rpm}$ for $15 \mathrm{~min}$ for cadmium analysis by ICP Optima 8000 Inductively coupled plasma (PerkinElmer, Waltham, MA, USA) at $228.8 \mathrm{~nm}$. The $\mathrm{Cd}^{2+}$ sorption rate was calculated using Equation (1). Three biological replicates were used in the experimental design.

$$
\text { Sorption rate }=\frac{C i-C f}{C i} \times 100 \%
$$

where $C i$ and $C f$ are the initial and final $\mathrm{Cd}^{2+}$ concentrations $(\mathrm{mg} / \mathrm{L})$, respectively. 


\subsection{Adsorption Kinetic Models}

The adsorption kinetic models experiments were conducted by adding the dried biomass (10 mg) into $50 \mathrm{~mL}$ of $50 \mathrm{mg} / \mathrm{L}$ cadmium solutions and then adsorbing for $48 \mathrm{~h}$ at $30{ }^{\circ} \mathrm{C}$. Dried biomass adsorption kinetic models were analyzed by using Lagergren pseudo-first-order (Equation (2)) and pseudo-second-order models (Equation (3)):

$$
\begin{gathered}
1 / Q_{t}=K_{1} /\left(Q_{m} t\right)+1 / Q_{m}, \text { and } \\
t / Q_{t}=1 / K_{2} Q_{m}^{2}+t / Q_{m}
\end{gathered}
$$

where $Q_{m} t$ is the metal concentrations at each time point, and $Q_{m}(\mathrm{mg} / \mathrm{g})$ is the maximum mass. $K_{1}$ is kinetic rate constant (/min), and $K_{2}$ is pseudo-second kinetic rate constant $(\mathrm{g} \cdot \mathrm{mg} / \mathrm{min})$.

\subsection{Statistical Analysis}

Our data are expressed as mean \pm S.D. and use IBM SPSS Statistics 22.0 (IBM Software Inc., New York, NY, USA) to analyze significant differences. The value of $p<0.05$ were considered statistically significant.

\section{Results}

\subsection{Metal Contents of Sediment and Screening of $\mathrm{Cd}^{2+}$-Resistant Bacteria}

Heavy metal contents in the sediment sample are presented in Table 1 . The $\mathrm{pH}$ of the river in Hejia station was $8.62 \pm 0.16$, which is alkaline. Cadmium $(2.51 \pm 0.21 \mathrm{mg} / \mathrm{kg})$ in sediment samples was 11.61 times higher than the local background value $(0.199 \mathrm{mg} / \mathrm{kg})$. Other metal ions were lower than the local background value. The total heterotrophic bacterial (THB) level was 5.6-6.4 × $10^{5} \mathrm{CFU} / \mathrm{g}$. A strain of bacteria showed the highest resistance against $\mathrm{Cd}^{2+}(150 \mathrm{mg} / \mathrm{L})$ after increasing $\mathrm{Cd}^{2+}$ concentration from 20 to $200 \mathrm{mg} / \mathrm{L}$, which was dubbed as H5 and selected for further studies.

Table 1. Metal concentration $(\mathrm{mg} / \mathrm{kg})$ in sampling spots of the study area.

\begin{tabular}{cc}
\hline Parameters & Value \\
\hline Latitude & $45^{\circ} 75^{\prime} 47^{\prime \prime} \mathrm{N}$ \\
Longitude & $126^{\circ} 57^{\prime} 57^{\prime \prime} \mathrm{E}$ \\
sampling spots number & 6 \\
Water temperature $\left({ }^{\circ} \mathrm{C}\right)$ & 4 \\
Water $\mathrm{pH}$ & $8.62 \pm 0.16$ \\
$\mathrm{Cd}$ & $2.51 \pm 0.21$ \\
$\mathrm{Ni}$ & $7.64 \pm 0.14$ \\
$\mathrm{Cu}$ & $6.14 \pm 0.54$ \\
$\mathrm{Cr}$ & $14.46 \pm 0.32$ \\
$\mathrm{~Pb}$ & $18.32 \pm 1.21$ \\
$\mathrm{Zn}$ & $26.86 \pm 1.84$ \\
$\mathrm{THB}$ level $(\mathrm{CFU} / \mathrm{g})$ & $5.6-6.4 \times 10^{5}$ \\
\hline
\end{tabular}

Note: THB: total heterotrophic bacteria.

\subsection{Characterization and Identification of $\mathrm{Cd}^{2+}-$ Resistant Bacteria}

Isolated strain $\mathrm{H} 5$ was identified by morphology, biochemical characteristics, and the 16SrDNA ribotyping test. Biochemical and morphological characteristics of the strain $\mathrm{H} 5$ are summarized in Table 2. The strain H5 exhibited activities of lysine decarboxylase, galactosidase, cytochrome oxidase, arginine dihydrolase, and indol production. It could produce acid from sugars such as glucose and inositol, other than sucrose, mannitol, sorbitol, rhamnose, melibiose, amy-gdalin, and arabinose. It did not show activities of gelatin hydrolase, urease, or tryptophan decarboxylase, nor the production 
of $\mathrm{H}_{2} \mathrm{~S}$ and Voges-Proskauer. The fractional sequence of the $16 \mathrm{SrDNA}$ gene of strain $\mathrm{H} 5$ was a $99 \%$ identical match with P. shigelloides JT-0601 according to the NCBI Reference Sequence Database. The resultant tree topologies were evaluated by bootstrap analysis of neighbor-joining data sets based on 1000 resamplings, and the phylogenetic tree is shown in Figure 1.

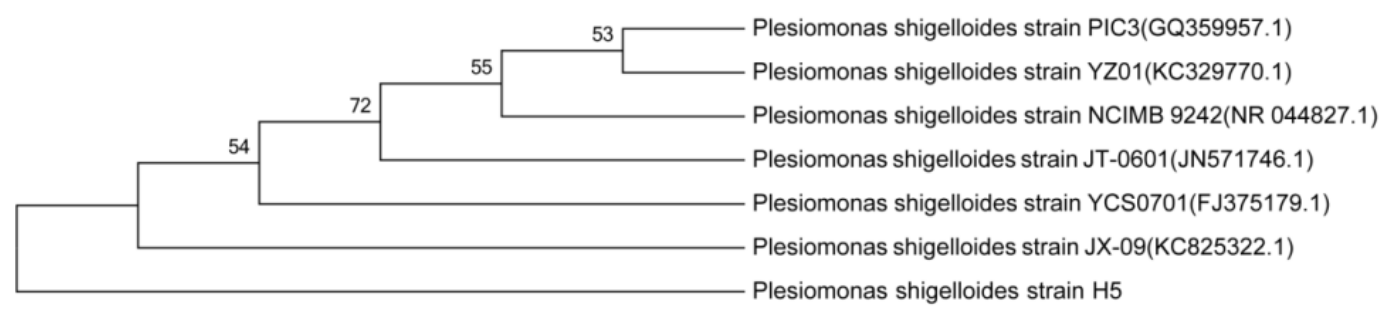

Figure 1. Phylogenetic tree for 16SrDNA gene sequences of P. shigelloides H5.

Table 2. Morphological and biochemical characteristics of P. shigelloides H5.

\begin{tabular}{cc}
\hline Strain & H5 \\
\hline Morphology & Yellowish \\
Colony color & - \\
Gram nature & Straight rod \\
Cell morphology & + \\
Motility & Round \\
Colony shape & Raised \\
Elevation & Smooth \\
Surface & Opaque \\
Optical &
\end{tabular}

\begin{tabular}{cc}
\hline Biochemical tests & \\
Lysine decarboxylase & - \\
Urease & + \\
Arginine dihydrolase & + \\
Indol production & + \\
O-nitrophenyl D-galactoside & - \\
$\mathrm{H}_{2}$ S production & - \\
Gelatin hydrolysis & - \\
Citrate & + \\
Inositol & + \\
Glucose & - \\
Sucrose & - \\
Mannitol & - \\
Sorbitol & - \\
Rhamnose & - \\
Melibiose & - \\
Amy-gdalin & - \\
Arabinose & - \\
Tryptophan & - \\
Voges-Proskauer & + \\
Cytochrome oxidase &
\end{tabular}

Notes: -: negative; +: positive.

\subsection{Optimal Culture Conditions}

Beef extract and peptone, as the nitrogen source and carbon sources, were used to determine the optimum growth conditions of strain $\mathrm{H} 5$. Optimal culture conditions of strain $\mathrm{H} 5$ were $\mathrm{pH} 7.0$ and $35^{\circ} \mathrm{C}$ in BEP medium and are presented in Figures 2 and 3. 


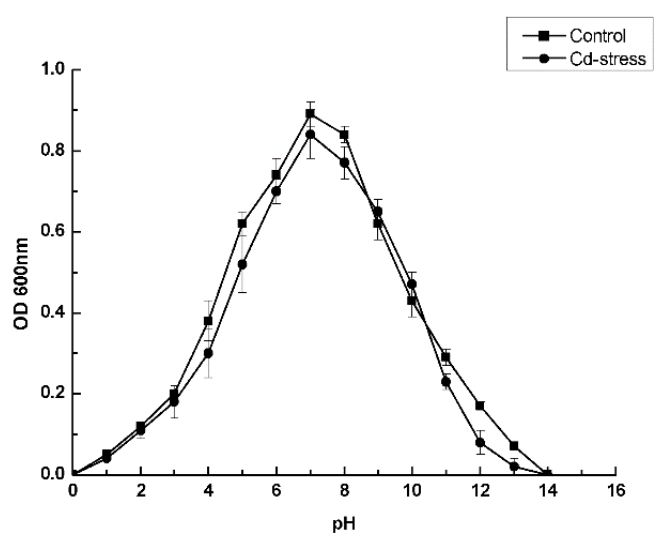

Figure 2. The optimum $\mathrm{pH}$ of $P$. shigelloides $\mathrm{H} 5$ with and without $\mathrm{Cd}^{2+}$ stress. $(p=0.007)$.

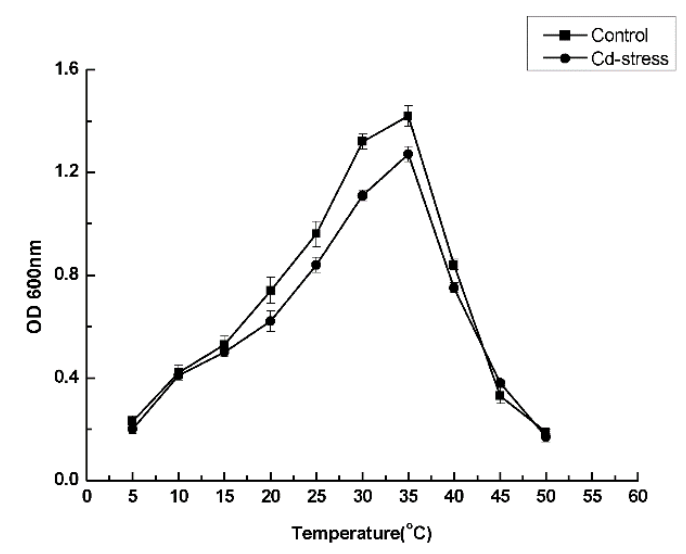

Figure 3. The optimum temperature of P. shigelloides $\mathrm{H} 5$ with and without $\mathrm{Cd}^{2+}$ stress. $(p=0.016)$.

\subsection{Maximum Tolerance Concentrations}

Compared with the control group, the growth rate of strain H5 decreased gradually with the increase of $\mathrm{Cd}^{2+}$ concentration in the experimental group. Figure 4 shows that higher $\mathrm{Cd}^{2+}$ concentration had an important influence on the growth rate of bacteria. Maximum tolerance concentration of strain $\mathrm{H} 5$ is $150 \mathrm{mg} / \mathrm{L}$. In the control group, the bacteria reached the stationary phase at $14 \mathrm{~h}$. However, in the experimental group with $\mathrm{Cd}^{2+}$ stress, the strain $\mathrm{H} 5$ reached the stationary phase at 16 to $20 \mathrm{~h}$.

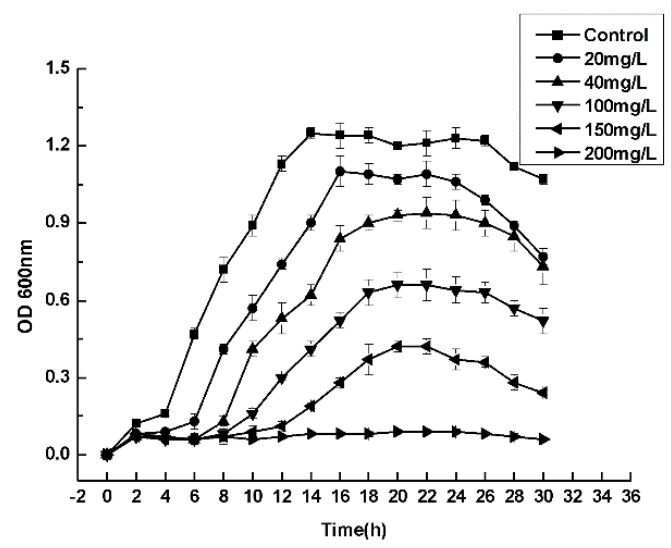

Figure 4. Maximum tolerance concentrations test of P. shigelloides H5. ( $p=0.000)$. 


\subsection{FTIR, SEM, EDX, and TEM Analysis}

In FTIR analysis, characteristic peaks of carboxyl, amino, and phosphate groups were observed, which confirmed the presence of these moieties in strain H5. Figure 5 shows that, in the presence of $\mathrm{Cd}^{2+}$, the amide linkage peaks appearing at 1657.79 and $1541.19 \mathrm{~cm}^{-1}$ were shifted to 1680.29 and $1568.05 \mathrm{~cm}^{-1}$, respectively. In SEM analysis, the surface morphologies of the adsorbed $\mathrm{Cd}^{2+}$ strain $\mathrm{H} 5$ was distinct from the wild-type strain $\mathrm{H} 5$. Figure $6 \mathrm{~B}$ shows that the outer membrane of strain $\mathrm{H} 5$ after $\mathrm{Cd}^{2+}$ biosorption became rougher, and the volume became bigger than the wild-type strain $\mathrm{H} 5$ as shown in Figure 6A. EDX result shows that $\mathrm{Cd}^{2+}$ was along with the surface of bacteria (Figure 7). TEM results show that some precipitates formed in cells after they were cultured in $\mathrm{Cd}^{2+}$ solution (Figure 8B) and is compared with the control group (Figure 8A).

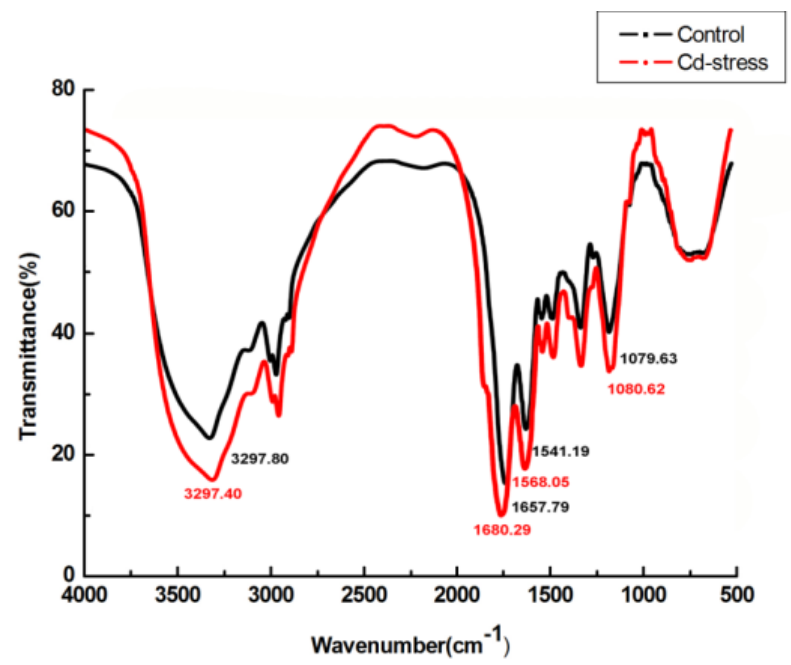

Figure 5. FTIR image of $P$. shigelloides $\mathrm{H} 5$ with and without $\mathrm{Cd}^{2+}$ stress.
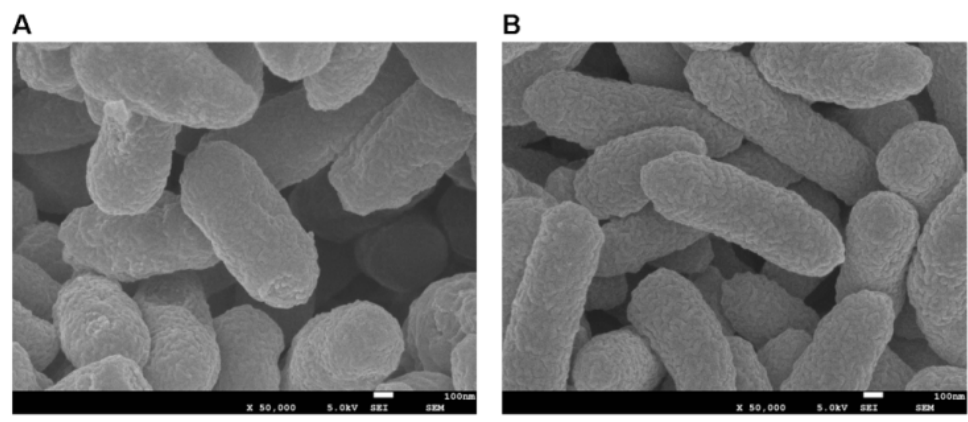

Figure 6. SEM images of $P$. shigelloides $\mathrm{H} 5$ without $\mathrm{Cd}^{2+}$ stress $(\mathbf{A})$ and with $\mathrm{Cd}^{2+}$ stress (B).

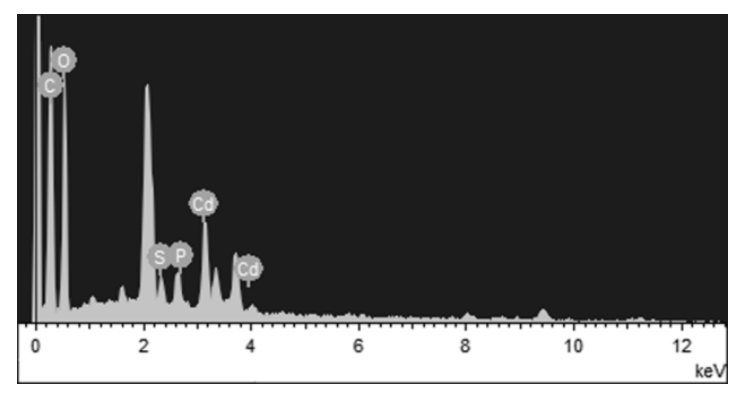

Figure 7. EDX image of $P$. shigelloides $\mathrm{H} 5$ with $\mathrm{Cd}^{2+}$ stress. 

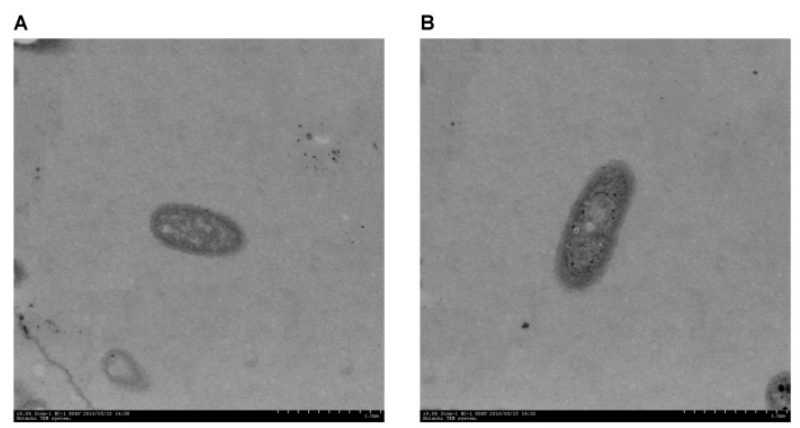

Figure 8. TEM images of $P$. shigelloides $\mathrm{H} 5$ without absorbing $\mathrm{Cd}^{2+}(\mathbf{A})$ and after absorbing $\mathrm{Cd}^{2+}(\mathbf{B})$.

\subsection{Cadmium Sorption Experiments}

As shown in Figures 9 and 10, pH has a great impact on the sorption rate. With the increase of $\mathrm{pH}$, the sorption rate was obviously improved. Maximum adsorption rate occurred at $\mathrm{pH}$. However, temperature has no significant impact on the sorption efficiency. The sorption rate of strain H5 is illustrated in Figure 11. The equilibrium sorption rate of living biomass and dried biomass were $48.91 \%$ $\pm 0.46 \%$ and $42.71 \% \pm 0.88 \%$, respectively. $\mathrm{Cd}^{2+}$ was rapidly combined with $P$. shigelloides $\mathrm{H} 5 \mathrm{during}$ the initial $60 \mathrm{~min}$, and both biomass sorption patterns then reached a stable condition at $480 \mathrm{~min}$. The equilibrium sorption amounts of $P$. shigelloides $H 5$ were $122.275 \pm 1.15 \mathrm{mg} / \mathrm{g}$ and $106.775 \pm 2.325 \mathrm{mg} / \mathrm{g}$. The maximum $\mathrm{Cd}^{2+}$ sorption rate of E. coli $\mathrm{DH} 5 \alpha$ was $11.42 \% \pm 0.16 \%$. This result indicated that the sorption rate of $P$. shigelloides H5 was four times that of the control E. coli DH5 $\alpha$ (Table 3).

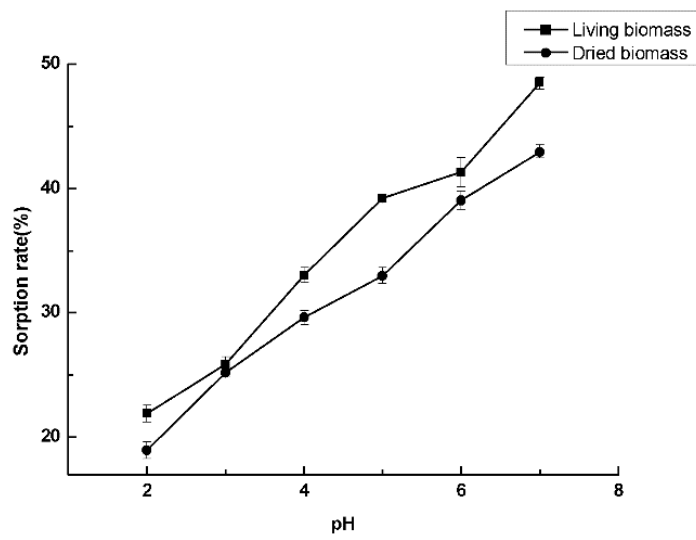

Figure 9. $\mathrm{pH}$ effect of both biomass sorption patterns. $(p=0.009)$.

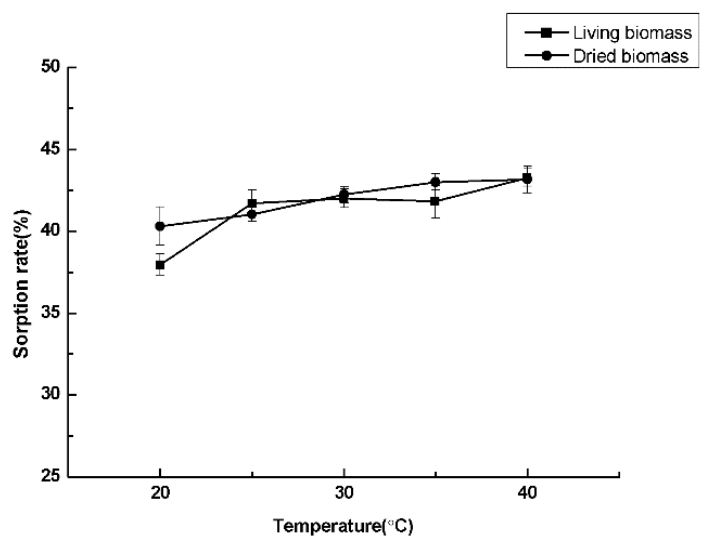

Figure 10. Temperature effect of both biomass sorption patterns. $(p=0.048)$. 


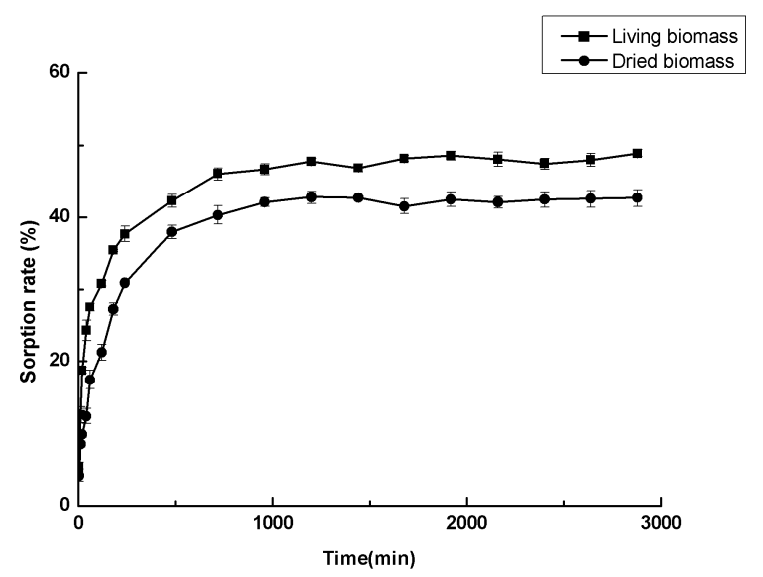

Figure 11. The equilibrium sorption curve of both biomass sorption patterns. $(p=0.000)$.

Table 3. The sorption ability of P. shigelloides $\mathrm{H} 5$ compared to E. coli $\mathrm{DH} 5 \alpha$.

\begin{tabular}{ccc}
\hline Living Biomass & Sorption Rate (\%) & Sorption Amounts (mg/g) \\
\hline P. shigelloides H5 & $48.91 \pm 0.46$ & $122.275 \pm 1.15$ \\
E. coli DH5 $\alpha$ & $11.42 \pm 0.16$ & $28.55 \pm 0.41$ \\
\hline
\end{tabular}

\subsection{Adsorption Kinetic Models}

The biosorption of $\mathrm{Cd}^{2+}$ by dried biomass was a rapid process and occurred in three periods. During the initial period, the adsorption rate increased rapidly; after $60 \mathrm{~min}, \mathrm{Cd}^{2+}$ adsorption began to slow down and then stabilized as it reached equilibrium after $480 \mathrm{~min}$. The fitting results show that the adsorption process of dried biomass was in accordance with Lagergren pseudo-second-order models (Table 4).

Table 4. Simulation of sorption kinetic equations and corresponding parameters.

\begin{tabular}{cccc}
\hline Models & $\boldsymbol{K}_{\mathbf{1}}$ or $\boldsymbol{K}_{\mathbf{2}}$ & $\boldsymbol{Q}_{\boldsymbol{m}}$ & $\boldsymbol{R}^{\mathbf{2}}$ \\
\hline Lagergren pseudo-first-order & 0.0017 & 0.1392 & 0.7577 \\
Lagergren pseudo-second-order & 0.0003 & 109.891 & 0.9992 \\
\hline
\end{tabular}

\section{Discussion}

Many indigenous species of microorganisms have the capacity to tolerate heavy metals, for example, Enterococcus faecalis, Escherichia coli, Bosea sp., and Bacillus catenulatus [12,20-23]. However, mutations can occur in some microorganisms due to the contamination of heavy metals in the environment. These evolved microorganisms have different mechanisms to tolerate or adsorb heavy metal ions, such as active efflux of toxic ions and enzymatic detoxification [24-27]. In previous studies, scientists discovered that $P$. shigelloides caused fish and human diseases. Affected fish showed a blackening of body color, a hemorrhage on the surface, and fin rotting, and P. shigelloides can also cause gastroenteritis in human [28,29]. However, no researchers have found that $P$. shigelloides can adsorb cadmium ions in a polluted environment. In this research, we isolated $P$. shigelloides from cadmium-polluted river sediment and discovered that it has the ability to adsorb cadmium ions from aqueous solutions. The isolated strain was very similar to P. shigelloides JT-0601, based on the fractional 16SrDNA gene sequences alignment, and the morphological and biochemical characteristics tests. Therefore, isolated strain was designated as Plesiomonas shigelloides H5.

$\mathrm{pH}$ and temperature are two important factors in affecting the growth of $P$. shigelloides $\mathrm{H} 5$. Although $P$. shigelloides $\mathrm{H} 5$ was obtained from river sediment having an alkaline $\mathrm{pH}$ at 8.62, results 
showed that its optimum $\mathrm{pH}$ is 7.0. Just like other bacteria, the P. shigelloides H5 cannot grow in extreme acidic and alkaline $\mathrm{pH}$ in BEP medium. Studying the effect of different temperatures revealed that $35{ }^{\circ} \mathrm{C}$ was the optimum temperature for $P$. shigelloides $\mathrm{H} 5$ because, as the temperature rises, the enzymes of bacterium speed up metabolism, but, when the temperature is too low or too high, enzymes are inactivated in the bacterial organism, which finally leads to the stoppage of growth. Furthermore, with the increase in cadmium ion concentration, the bacteria growth rate slows significantly, and OD600 values clearly decrease, which might be due to cadmium ions' considerably toxic effect on Gram-negative bacteria [30]. The maximum tolerance concentration of P. shigelloides $\mathrm{H} 5 \mathrm{is} 150 \mathrm{mg} / \mathrm{L}$. Statistical analysis results are $p<0.05$, which indicates that the Cd-stress group is significantly different from the control group. This implies that $\mathrm{Cd}^{2+}$ can affect the growth of bacteria. FTIR results show $\mathrm{N}-\mathrm{H}$ bending and $\mathrm{C}-\mathrm{O}$ stretching, which means that the protein amide band II was active in the adsorption of $\mathrm{Cd}^{2+}$. The intensity of the bands varied in different regions after the interaction with $\mathrm{Cd}^{2+}$. These results are similar to the findings by Khan [23]. SEM results revealed that P. shigelloides H5 adapts to high concentrations of cadmium ions in the environment by increasing the volume, which is similar to findings by Wu and Sun [22]. EDX results indicate that the outer membrane of P. shigelloides $\mathrm{H} 5$ was involved in the adsorption of heavy metals, as Kim reported [31]. One previous study found that bacteria can transport metal ions into the cells by passive transport or by an outmembrane's $\mathrm{Mn}^{2+} / \mathrm{Zn}^{2+} / \mathrm{Ca}^{2+}$ transporter [22]. The intracellular $\mathrm{Cd}^{2+}$ can combine with phosphate to perform precipitate, or $\mathrm{Cd}^{2+}$ toxicity can cause a cadmium efflux pump CzcCBA to efflux $\mathrm{Cd}^{2+}$ in order to reduce damage [23]. In this study, it was found that living biomass can adsorb more cadmium ions than dried biomass and that some precipitates formed in P. shigelloides H5 after being cultured in $\mathrm{Cd}^{2+}$ solution, which indicated that living biomass can absorb $\mathrm{Cd}^{2+}$ in cells, but adsorption amounts were much lower than adsorption amounts (Figures 8 and 11). Therefore, we will focus on the absorption mechanism and precipitate constituents in future research. In the experiment of the $\mathrm{pH}$ effect, the maximum sorption rate occurred at $\mathrm{pH} 7$, which indicates that, with the decrease in hydrion, living biomass and dried biomass can effectively remove cadmium ions in solutions. The statistical analysis result was $p=0.009(p<0.01)$, which indicated that living biomass is extremely different from dried biomass under different $\mathrm{pH}$-values. As for the TEM results, it is hypothesized that living biomass can absorb partial $\mathrm{Cd}^{2+}$ into the cells and cause a difference. This experiment did not study biological sorption in alkaline solutions because cadmium ions and hydroxyl ions can form a cadmium hydroxide precipitant in solutions. Therefore, an aqueous solution should be adjusted in the neutral $\mathrm{pH}$ to improve sorption efficiency in future practical applications. However, the temperature has a slight effect on the sorption efficiency experiment, which can be applied to actual pollution control in the future. There are no significant differences between both sorption patterns $(p=0.328)$. We consider sometimes that the adsorption capacity of living biomass may be weak in affecting the whole entire process. On the basis of the plot in Figure 11 and of Table 4, both biomass sorption patterns can reach a stable condition at $480 \mathrm{~min}$. There are extremely significant differences between both biomass patterns $(p=0.000)$. Dried biomass was in accordance with Lagergren pseudo-second-order models. The sorption process was composed of three periods. The first period was attributed to the large number of vacant active sites on the dried biomass surface, to electrostatic adherence cadmium ions. The second period was attributed to the fact that the adsorption rate gradually decreases as vacant active sites decrease. The third period is the final equilibrium in which the vacant active sites were all combined with cadmium ions. Similar results are also reported in a previous study [21]. Furthermore, the sorption rate of P. shigelloides $\mathrm{H} 5$ was four times that of the control E. coli DH5 $\alpha$, which can verify its effectiveness.

\section{Conclusions}

To sum up, we have successfully isolated the cadmium-resistant strain Plesiomonas shigelloides H5, which can adsorb cadmium ions in solution. The surface functional groups of P. shigelloides H5 can participate in the adsorption of cadmium ions from aqueous solutions. Adsorption kinetic models 
of dried biomass were in accordance with Lagergren pseudo-second-order models, and equilibrium adsorption amounts was $106.775 \pm 2.325 \mathrm{mg} / \mathrm{g}$. Dried biomass can also achieve adsorption saturation in a short time. A preliminary study found that P. shigelloides $\mathrm{H} 5$ can absorb a small amount of $\mathrm{Cd}^{2+}$ into cells to form precipitates. The present study indicated that $P$. shigelloides $\mathrm{H} 5$ can be applied in wastewater treatment in the future.

Acknowledgments: This study was financially supported by the Major Science and Technology Program for Water Pollution Control and Treatment (No. 2013ZX07201007).

Author Contributions: Chao Xue conceived and designed the experiments, performed the analysis, and analyzed the data. Mengsha Li and Yunzhi Liu provided experimental guidance. All authors (Chao Xue, Peishi Qi, Mengsha Li and Yunzhi Liu) contributed to the writing of the paper.

Conflicts of Interest: The authors declared no conflict of interest.

\section{References}

1. Sanità di Toppi, L.; Gabbrielli, R. Response to cadmium in higher plants. Environ. Exp. Bot. 1999, 41, 105-130. [CrossRef]

2. Radotić, K.; Dučić, T.; Mutavdžić, D. Changes in peroxidase activity and isoenzymes in spruce needles after exposure to different concentrations of cadmium. Environ. Exp. Bot. 2000, 44, 105-113. [CrossRef]

3. Zhao, L.; You, W.; Hu, H.; Hong, W.; Liao, X.; Xiao, S.; Wang, R.; Cai, J.; Fan, X.; Tan, Y. Spatial distribution of heavy metals $(\mathrm{Cu}, \mathrm{Pb}, \mathrm{Zn}$, and $\mathrm{Cd})$ in sediments of a coastal wetlands in eastern Fujian, China. J. For. Res. 2015, 26, 703-710. [CrossRef]

4. AMAP Assessment 2011: Mercury in the Arctic; Arctic Monitoring and Assessment Programme: Oslo, Norway, 2011.

5. Filipič, M.; Fatur, T.; Vudrag, M. Molecular mechanisms of cadmium induced mutagenicity. Hum. Exp. Toxicol. 2006, 25, 67-77. [CrossRef] [PubMed]

6. Benavides, M.P.; Gallego, S.M.; Tomaro, M.L. Cadmium toxicity in plants. Braz. J. Plant Physiol. 2005, 17, 21-34. [CrossRef]

7. Flora, S.J.S.; Megha, M.; Ashish, M. Heavy metal induced oxidative stress \& its possible reversal by chelation therapy. Indian J. Med. Res. 2008, 128, 501-523. [PubMed]

8. Bai, H.; Zhang, Z.; Yang, G.; Li, B. Bioremediation of cadmium by growing rhodobacter sphaeroides: Kinetic characteristic and mechanism studies. Bioresour. Technol. 2008, 99, 7716-7722. [CrossRef] [PubMed]

9. Halttunen, T.; Salminen, S.; Tahvonen, R. Rapid removal of lead and cadmium from water by specific lactic acid bacteria. Int. J. Food Microb. 2007, 114, 30-35. [CrossRef] [PubMed]

10. Roane, T.M.; Pepper, I.L. Microbial responses to environmentally toxic cadmium. Microb. Ecol. 1999, 38, 358-364. [CrossRef] [PubMed]

11. Abbas, S.Z.; Rafatullah, M.; Ismail, N.; Lalung, J. Isolation, identification, characterization, and evaluation of cadmium removal capacity of enterobacter species. J. Basic Microb. 2014, 54, 1279-1287. [CrossRef] [PubMed]

12. Neethu, C.S.; Mujeeb Rahiman, K.M.; Saramma, A.V.; Mohamed Hatha, A.A. Heavy-metal resistance in Gram-negative bacteria isolated from Kongsfjord, Arctic. Can. J. Microb. 2015, 61, 429-435. [CrossRef] [PubMed]

13. Pérez-Rama, M.; Torres, E.; Suárez, C.; Herrero, C.; Abalde, J. Sorption isotherm studies of Cd(II) ions using living cells of the marine microalga Tetraselmis suecica (Kylin) Butch. J. Environ. Manag. 2010, 91, 2045-2050. [CrossRef] [PubMed]

14. Yang, Y.; Xie, Y.; Li, X. Characterization of biological iron sulfide composites and its application in the treatment of cadmium-contaminated wastewater. J. Environ. Biol. 2015, 36, 393-398. [PubMed]

15. Vullo, D.L.; Ceretti, H.M.; Daniel, M.A.; Ramírez, S.A.M.; Zalts, A. Cadmium, zinc and copper biosorption mediated by Pseudomonas veronii 2E. Bioresour. Technol. 2008, 99, 5574-5581. [CrossRef] [PubMed]

16. Kılıç, N.K.; Dönmez, G. Environmental conditions affecting exopolysaccharide production by Pseudomonas aeruginosa, Micrococcus sp., and Ochrobactrum sp. J. Hazard. Mater. 2008, 154, 1019-1024. [CrossRef] [PubMed]

17. Harrison, J.J.; Ceri, H.; Stremick, C.; Turner, R.J. Differences in biofilm and planktonic cell mediated reduction of metalloid oxyanions. FEMS Microbiol. Lett. 2004, 235, 357-362. [CrossRef] [PubMed] 
18. Coral, G.; Arıkan, B.; Coral, M.N.Ü. A preliminary study on tellurite resistance in Pseudomonas spp. isolated from hospital sewage. Pol. J. Environ. Stud. 2006, 15, 517-520.

19. Dewhirst, F.E.; Chien, C.C.; Paster, B.J.; Ericson, R.L.; Orcutt, R.P.; Schauer, D.B.; Fox, J.G. Phylogeny of the defined murine microbiota: Altered schaedler flora. Appl. Environ. Microbiol. 1999, 65, 3287-3292. [PubMed]

20. Xie, X.H.; Jin, F.; Wang, H.P.; Liu, J.S. Heavy metal resistance by two bacteria strains isolated from a copper mine tailing in China. Afr. J. Biotechnol. 2010, 9, 4056-4066.

21. Zhang, H.; Liu, L.; Chang, Q.; Wang, H.; Yang, K. Biosorption of Cr(VI) ions from aqueous solutions by a newly isolated Bosea sp. strain Zer-1 from soil samples of a refuse processing plant. Can. J. Microbiol. 2015, 61, 399-408. [CrossRef] [PubMed]

22. Wu, G.; Sun, M.; Liu, P.; Zhang, X.; Yu, Z.; Zheng, Z.; Chen, Y.; Li, X. Enterococcus faecalis strain LZ-11 isolated from Lanzhou reach of the Yellow River is able to resist and absorb Cadmium. J. Appl. Microbiol. 2014, 116, 1172-1180. [CrossRef] [PubMed]

23. Khan, Z.; Nisar, M.A.; Hussain, S.Z.; Arshad, M.N.; Rehman, A. Cadmium resistance mechanism in Escherichia coli $\mathrm{P} 4$ and its potential use to bioremediate environmental cadmium. Appl. Microbiol. Biotechnol. 2015, 99, 10745-10757. [CrossRef] [PubMed]

24. Silver, S.; Le, T.P. A bacterial view of the periodic table: Genes and proteins for toxic inorganic ions. J. Ind. Microbiol. Biotechnol. 2005, 32, 587-605. [CrossRef] [PubMed]

25. Nies, D.H. Efflux-mediated heavy metal resistance in prokaryotes. FEMS Microbiol. Rev. 2003, 27, 313-339. [CrossRef]

26. Malin Mejare, L.B. Metal-binding proteins and peptides in bioremediation and phytoremediation of heavy metals. TRENDS Biotechnol. 2001, 19, 67-73. [CrossRef]

27. Piddock, L.J.V. Multidrug-resistance efflux pumps? Not just for resistance. Nat. Rev. Microbiol. 2006, 4, 629-636. [CrossRef] [PubMed]

28. Matsuyama, R.; Kuninaga, N.; Morimoto, T.; Shibano, T.; Sudo, A.; Sudo, K.; Asano, M.; Suzuki, M.; Asai, T. Isolation and antimicrobial susceptibility of Plesiomonas shigelloides from great cormorants (Phalacrocorax carbo hanedae) in Gifu and Shiga Prefectures, Japan. J. Vet. Med. Sci. 2015, 77, 1179-1181. [CrossRef] [PubMed]

29. Novoa-Farias, O.; Frati-Munari, A.C.; Peredo, M.A.; Flores-Juarez, S.; Novoa-Garcia, O.; Galicia-Tapia, J.; Romero-Carpio, C.E. Susceptibility of bacteria isolated from acute gastrointestinal infections to rifaximin and other antimicrobial agents in Mexico. Rev. Gastroenterol. Mex. 2015, 91, 3-10. [CrossRef]

30. Tsuno, T.; Mejido, J.; Schmeisser, H.; Fey, S.; Morrow, A.; Nie, H.; Zhao, T.; Bekisz, J.; Goldman, N.; Zoon, K. Isolation and characterization of heavy-metal resistant microbes from roadside soil and phylloplane. Cotton Sci. 2012, 52, 53-65.

31. Kim, S.Y.; Jin, M.R.; Chung, C.H.; Yun, Y.S.; Jahng, K.Y.; Yu, K.Y. Biosorption of cationic basic dye and cadmium by the novel biosorbent Bacillus catenulatus JB-022 strain(environmental biotechnology). J. Biosci. Bioeng. 2015, 119, 433-439. [CrossRef] [PubMed]

(C) 2016 by the authors; licensee MDPI, Basel, Switzerland. This article is an open access article distributed under the terms and conditions of the Creative Commons Attribution (CC-BY) license (http://creativecommons.org/licenses/by/4.0/). 